\title{
Which Is Better EGFR-TKI Followed by Osimertinib: Afatinib or Gefitinib/Erlotinib?
}

\author{
MOTOHIRO TAMIYA ${ }^{1}$, AKIHIRO TAMIYA ${ }^{2}$, HIDEKAZU SUZUKI ${ }^{3}$, KAZUNORI MORIIZUMI $^{3}$, \\ KENJI NAKAHAMA ${ }^{2}$, YOSHIHIKO TANIGUCHI ${ }^{2}$, KEI KUNIMASA ${ }^{1}$, MADOKA KIMURA ${ }^{1}$, \\ TAKAKO INOUE ${ }^{1}$, HANAKO KUHARA ${ }^{1}$, KAZUMI NISHINO ${ }^{1}$, \\ TOMONORI HIRASHIMA ${ }^{3}$, SHINJI ATAGI ${ }^{4}$, FUMIO IMAMURA ${ }^{1}$ and TORU KUMAGAI ${ }^{1}$ \\ ${ }^{1}$ Department of Thoracic Oncology, Osaka International Cancer Institute, Osaka, Japan; \\ ${ }^{2}$ Department of Internal Medicine, Kinki-chuo Chest Medical Center, Sakai, Japan; \\ ${ }^{3}$ Department of Thoracic Oncology, Osaka Habikino Medical Center, Habikino, Japan; \\ ${ }^{4}$ Clinical Research Center, Kinki-chuo Chest Medical Center, Sakai, Japan
}

\begin{abstract}
Background/Aim: Treatment with EGFR-tyrosine kinase inhibitor (TKI) shows a durable response against NSCLC harboring EGFR mutation; however, treatment resistance occurs within 1-1.5 years following first-line EGFR-TKIs [first- and second-generation (G) TKIs]. When resistant NSCLC exhibits T790M mutations, osimertinib is the standard therapy. However, intratumoral heterogeneity and clonal evolution may occur in NSCLC. Afatinib may overcome tumor heterogeneity, leading to T790M colonal purity. We aimed to determine whether NSCLC treatment with afatinib followed by osimertinib (afatinib group) provides higher therapeutic efficacy than other 1 st-G EFGRTKIs followed by osimertinib (1st-G group). Materials and Methods: This multicenter retrospective study evaluated outcomes between afatinib group and 1 st-G group. We analyzed clinical data from NSCLC patients receiving osimertinib after progression following 1st- or 2nd-G EGFRTKIs between March 28, 2016 and March 31, 2018. Patients with performance status (PS) 0-2 were enrolled to reduce bias of patients' conditions. Results: We enrolled 111 patients treated with osimertinib. The median age was 69 (range: 39 88) years. Out of 111 patients, 33 (29.7\%) were men, 100 (90\%) had PS 0-1, and 35 (31.5\%) were in the afatinib group. The objective RR and DCR were significantly higher in the afatinib group than in the 1st-G group [82.9\% vs. $53.9 \%(p=0.0065) ; 91.4 \%$ vs. $71.1 \% \quad(p=0.032)]$. The
\end{abstract}

Correspondence to: Motohiro Tamiya, Department of Thoracic Oncology, Osaka International Cancer Institute, Otemae 3-1-69, Chuo-ku, Osaka City, Osaka 541-8567, Japan. Tel: +81 669451181, Fax: +81 669451900, e-mail: moto19781205@yahoo.co.jp

Key Words: Afatinib, osimertinib, T790M, EGFR mutation, sequential TKI-therapy. median PFS tended higher in the afatinib group than in the 1 st-G group (15.6 vs. 8.9 months, $p=0.195)$. Conclusion: Afatinib followed by osimertinib may provide better outcomes for T790M-positive NSCLC than 1st-G EGFRTKIs. Afatinib followed by osimertinib may be a therapeutic option for NSCLC harboring EGFR mutation.

Approximately $75 \%$ of all lung cancer cases, the most common cause of cancer-related death worldwide, are nonsmall cell lung cancer (NSCLC) (1). Although the efficacy of platinum-based doublet chemotherapy, the standard treatment for advanced NSCLC for decades, seems to have plateaued (2), molecular-targeted chemotherapeutics have the potential to increase efficacy in some patients (3). EGFR tyrosine kinase inhibitors (TKIs), such as first-generation (1st-G) EGFR-TKIs (gefitinib and erlotinib), treatment exhibit higher response rates (RRs), longer progression-free survival (PFS), and better tolerability in NSCLC patients harboring epidermal growth factor receptor (EGFR) mutations compared to treatment with standard platinumbased chemotherapy (4-7). Moreover, afatinib, a second generation (2nd-G) EGFR-TKI, shows longer overall survival (OS), higher RR, and longer PFS than standard cytotoxic chemotherapy (8). Furthermore, afatinib exhibits significant improvements in PFS [hazard ratio (HR): 0.73, 95\% confidence interval (CI): 0.57-0.95; $p=0.017$ ] compared with gefitinib in patients with common $E G F R$ mutations (Del 19 and L858R), as seen in the LUX-Lung 7 trial (9).

Although EGFR-TKI treatment showed durable response against NSCLC harboring EGFR mutations, most cases experience cancer relapse within 1-1.5 years following treatment initiation with first-line 1st- and 2nd-G EGFRTKIs (4-8). In many of these cases, acquired resistance is observed when a subsequent biopsy is obtained. Therefore, a key consideration when assessing therapeutic choice is the 
evaluation of mechanism following disease progression. The most common mechanism of resistance to $1 \mathrm{st}$ - and $2 \mathrm{nd}-\mathrm{G}$ EGFR-TKI treatment is a T790M mutation where threonine is substituted with methionine at the 790th amino-acid codon on exon 20 of the EGFR gene, this mutation is present in approximately $50 \%$ of tumors at time of acquired resistance (10-13).

Osimertinib, an oral irreversible EGFR-TKI, was shown to specifically block EGFR-T790M with minimal inhibition of wild-type EGFR (14). These results lead to initiation of clinical trials that demonstrated excellent outcomes in NSCLC patients with T790M mutation yielding a response rate of $61 \%$ and PFS of 9.6 months (15). A phase III trial (AURA III) was undertaken to compare platinum combination chemotherapy and osimertinib in patients with EGFR-TKI-sensitive mutation harboring lung cancers that showed exacerbation during or after EGFR-TKI treatment (16). In that study, osimertinib exceeded pemetrexed plus platinum therapy with statistical significance in PFS (10.1 vs. 4.4 months; $\mathrm{HR}=0.30, p<0.001)$.

Although osimertinib exhibits enhanced efficacy on RR (for $80 \%$ vs. 76\%; $p=0.24$ ) and PFS (for $18.9 v s .10 .2$ months; $\mathrm{HR}=0.46, p<0.001)$ compared to $1 \mathrm{st}-\mathrm{G}$ EGFR-TKIs (17), there are no molecular targets of therapy due to the heterogeneity of resistance mechanisms that are not well understood or currently undruggable $(18,19)$. As a result, in the course of clinical practice for most patients following cancer progression after osimertinib treatment, chemotherapy is the only remaining option for second-line treatment.

Therefore, in treating patients with sequential EGFRTKIs, it may prove efficacious to reserve osimertinib use as a second-line option to maximize treatment time on targeted drugs. However, there is little data assessing the cumulative benefit of sequential EGFR-TKIs in NSCLC patients harboring $E G F R$ mutations $(20,21)$. One multicenter observational study assessed total treatment duration of sequential afatinib and osimertinib in NSCLC patients harboring the EGFR mutation with T790M-acquired resistance and showed good time on treatment (median: 27.6 months), afatinib (median PFS: 11.9 months) followed by osimertinib (median PFS: 14.3 months) (20). However, no study has attempted to assess if a given EGFR-TKI (gefitinib, erlotinib, afatinib) proves better in sequential therapy followed by osimertinib. Therefore, we analyzed the efficacy of these drugs in patients sequentially treated with osimertinib to evaluate an optimal sequential therapy in realworld clinical practice.

\section{Materials and Methods}

We conducted a multicenter retrospective study across three medical centers in Japan. The study design and methodology was approved by the Institutional Review Board of each participating institution.
Table I. Patient characteristics.

\begin{tabular}{|c|c|c|}
\hline Characteristics & $\begin{array}{l}\text { 1st-G group } \\
\quad \mathrm{N}=76\end{array}$ & $\begin{array}{l}\text { Afatinib group } \\
\qquad \mathrm{N}=35\end{array}$ \\
\hline \multicolumn{3}{|l|}{ Age } \\
\hline Median (range) & $70(41-88)$ & $64(39-84)$ \\
\hline \multicolumn{3}{|l|}{ Gender } \\
\hline Male/Female & $22 / 54$ & $11 / 24$ \\
\hline \multicolumn{3}{|l|}{ Smoking history } \\
\hline Never/Ever & $50 / 26$ & $18 / 17$ \\
\hline \multicolumn{3}{|l|}{ Performance Status } \\
\hline $0 / 1 / 2$ & $19 / 50 / 7$ & $9 / 22 / 4$ \\
\hline \multicolumn{3}{|l|}{ Histology } \\
\hline Adenocarcinoma/Others & $76 / 0$ & $35 / 0$ \\
\hline \multicolumn{3}{|l|}{ Sensitive $E G F R$ mutation } \\
\hline Exon 19 (deletion)/L858R & $37 / 39$ & $23 / 12$ \\
\hline \multicolumn{3}{|l|}{ Substance to be measured } \\
\hline Plasma/Cytology/Tissue & $19 / 12 / 45$ & $8 / 6 / 21$ \\
\hline \multicolumn{3}{|l|}{ The last EGFR-TKI } \\
\hline Gefitinib/Erlotinib/Afatinib & $31 / 45 / 0$ & $0 / 0 / 35$ \\
\hline \multicolumn{3}{|l|}{ Number of prior regimens } \\
\hline $1 / 2 / 3 / 4 / 5 / 6$ or more & $30 / 19 / 7 / 5 / 6 / 9$ & $2 / 4 / 5 / 10 / 3 / 11$ \\
\hline \multicolumn{3}{|l|}{ Response of the last EGFR-TKI } \\
\hline $\mathrm{CR} / \mathrm{PR} / \mathrm{SD} / \mathrm{PD} / \mathrm{NE}$ & $1 / 43 / 15 / 13 / 4$ & 0/10/13/11/1 \\
\hline Response rate/Disease control rate & $57.9 \% / 77.6 \%$ & $28.6 \% / 65.7 \%$ \\
\hline $\begin{array}{l}\text { Brain metastasis before osimertinib } \\
\text { none/meta }+\end{array}$ & $38 / 38$ & $15 / 20$ \\
\hline
\end{tabular}

1st-G group: the patients treated with afatinib followed by osimertinib. Afatinib group: the patients treated with 1st-generation EGFR-TKIs followed by osimertinib. CR: Complete response, PR: partial response, SD: stable diseases, PD: progression diseases, NE: not evaluated.

Research was conducted in accordance with the Declaration of Helsinki and the World Health Organization's Guidelines for Good Clinical Practice.

Patient selection. Cases with patients treated with osimertinib at the Osaka International Cancer Institute, the Osaka Habikino Medical Center and the National Hospital Organization Kinki-chuo Chest Medical Center were reviewed between March 28, 2016 (the date osimertinib was approved in Japan) and March 31, 2018. Study participants were consecutively enrolled among patients in routine practice according to the following criteria: patients with T790M mutation who were treated with osimertinib after acquired resistance to EGFR-TKIs at any time for advanced NSCLC and who had good Eastern Cooperative Oncology Group (ECOG) performance status (PS): 0-2, and major EGFR mutation (Exon19: deletion19 or Exon21: L858R) before initial EGFR-TKI treatment to reduce biasing toward patient conditions. Patients were excluded from our analysis if they had received osimertinib treatment as part of a clinical trial.

Data collection. Clinical data, including age, sex, smoking status, ECOG PS, EGFR mutation status, the place of re-biopsy and the content of all treatments, were collected from electronic medical records and pharmacy databases. EGFR mutation and T790M status were determined per local methodology and practices. Clinical responses were defined according to the Response Evaluation 
Table II. The efficacy of osimertinib following between afatinib and 1 st-G group.

\begin{tabular}{|c|c|c|c|c|c|c|c|c|}
\hline & $\mathrm{N}$ & $\mathrm{RR}(\%)$ & $\operatorname{DCR}(\%)$ & $\mathrm{CR}(\%)$ & PR $(\%)$ & $\mathrm{SD}(\%)$ & $\mathrm{PD}(\%)$ & NE $(\%)$ \\
\hline \multirow[t]{2}{*}{ All patients } & 111 & $63.1 \%$ & $78.4 \%$ & 2 & 68 & 17 & 17 & 7 \\
\hline & & & & $1.8 \%$ & $61.3 \%$ & $15.3 \%$ & $15.3 \%$ & $6.3 \%$ \\
\hline \multirow[t]{2}{*}{ Afatinib group } & 35 & $82.9 \%$ & $91.4 \%$ & 2 & 27 & 3 & 3 & 0 \\
\hline & & & & $5.7 \%$ & $77.1 \%$ & $8.6 \%$ & $8.6 \%$ & $0 \%$ \\
\hline \multirow[t]{2}{*}{ 1st-G group } & 76 & $53.9 \%$ & $72.4 \%$ & 0 & 41 & 14 & 14 & 7 \\
\hline & & & & $0 \%$ & $53.9 \%$ & $18.4 \%$ & $18.4 \%$ & $9.2 \%$ \\
\hline
\end{tabular}

1st-G group: the patients treated with afatinib followed by osimertinib. Afatinib group: the patients treated with 1st-generation EGFR-TKIs followed by osimertinib. RR: Response rate, DCR: diseases control rate, CR: complete response, PR: partial response, SD: stable diseases, PD: progression diseases, NE: not evaluated.

Criteria in Solid Tumors, version 1.1 (22). PFS was determined from the first administration date of osimertinib to the date of disease progression or death from any cause. Patients were followed-up until the March 31, 2018.

Statistical analyses. Kaplan-Meier curves were used to evaluate PFS, which was compared using the log-rank test. Median values and $95.0 \%$ CIs were also reported. Univariate and multivariate analyses were performed using Cox proportional hazards regression models. Only variables with a $p<0.05$ in the univariate analysis were included in the multivariate analysis. All statistical analyses were conducted using R software, version 2.8.1 (The R Foundation for Statistical Computing, Vienna, Austria). $p<0.05$ was considered a statistically significant difference and $p<0.15$ was considered to be moderately trending difference.

We classified patients treated with afatinib followed by osimertinib (afatinib group) or the patients treated with 1 st-G EGFR-TKI followed by osimertinib (1st-G group) by last administration of EGFR-TKI before osimertinib, evaluated the outcomes between the afatinib and $1 \mathrm{st}-\mathrm{G}$ groups.

\section{Results}

A total of one hundred eleven patients were assessed for eligibility. The median follow-up time was 14.3 (range $=1.0$ 25.2) months. The median age was 69 (range=39-88) years. Out of the 111 patients, $33(29.7 \%)$ were men, $68(61.3 \%)$ never smoked, 100 (90\%) had PS 0-1, $58(52.3 \%)$ had brain metastasis before treatment with osimertinib, all had adenocarcinoma, $60(54.1 \%)$ had exon 19 deletion and 28 $(25.2 \%)$ were measured in T790M status by liquid biopsy of plasma. Furthermore, $35(31.5 \%)$ were in the afatinib group and $76(68.5 \%)$ were in the $1 \mathrm{st}-\mathrm{G}$ group. Characteristics were generally consistent between groups, although the afatinib group had a higher median treatment line (5 vs. 4) than 1st$\mathrm{G}$ group. All patients received starting doses of $80 \mathrm{mg} /$ day osimertinib (Table I).

The objective RR and DCR of osimertinib across all study participants were $63.1 \%$ and $77.5 \%$ respectively, with the objective RR and DCR significantly higher in the afatinib group than in the 1 st-G group (82.9\% vs. $53.9 \%, p=0.0065$,
Table III. Survival measures comparing patients with brain metastases.

\begin{tabular}{lrrrc}
\hline & N & RR (\%) & DCR (\%) & CNS PD rate (\%) \\
\hline All patients & 111 & $63.1 \%$ & $78.4 \%$ & $16(14.4 \%)$ \\
Brain metastasis+ & 58 & $53.4 \%$ & $74.1 \%$ & $16(27.6 \%)$ \\
Brain metastasis- & 53 & $73.6 \%$ & $83.0 \%$ & $0(0 \%)$ \\
\hline
\end{tabular}

RR: Response rate, DCR: disease control rate, CNS PD rate: central nervous system disease progression rate.

and $91.4 \%$ vs. $71.1 \%, p=0.032$, respectively; Table II). Comparing patients with or without brain metastasis, the objective RR and DCR were $53.4 \%$ vs. $73.6 \%(p=0.046)$ and $74.1 \%$ vs. $83.0 \% \quad(p=0.366)$, respectively. The central nervous system PD rates of osimertinib were significantly higher in patients with brain metastasis than those without (27.6\% vs. $0 \%, p<0.001$; Table III).

The median PFS across all patients was 12.0 (95\%CI: 8.416.0) months, and OS was not achieved (Figure 1a and b). The median PFS was moderately higher in the afatinib group than in the $1 \mathrm{st}-\mathrm{G}$ group $[17.0(95 \% \mathrm{CI}=8.5$-infinity) $v s .9 .7$ (95\%CI=7.8-15.7) months; $p=0.164$; Figure 2a], and the median OS values were not significantly different between the groups ( $p=0.322$; Figure $2 \mathrm{~b})$.

\section{Discussion}

In the present study, we demonstrated that RR and DCR in the afatinib treated group is superior to those in 1st G EGFRTKI treated groups prior to osimertinib therapy. Furthermore, the sequential therapy using afatinib showed a trend for longer PFS than the sequential therapy using other 1 st-G TKIs. In a post-hoc analysis of the Lux-Lung7 trial, the median OS with afatinib $v s$. gefitinib in patients who received a 3rd-G EGFR-TKI following discontinuation of study treatment was not evaluable vs. 46.0 months $(\mathrm{HR}=0.51,95 \% \mathrm{CI}=0.17-1.52, p=0.22)(23)$. This post-hoc 

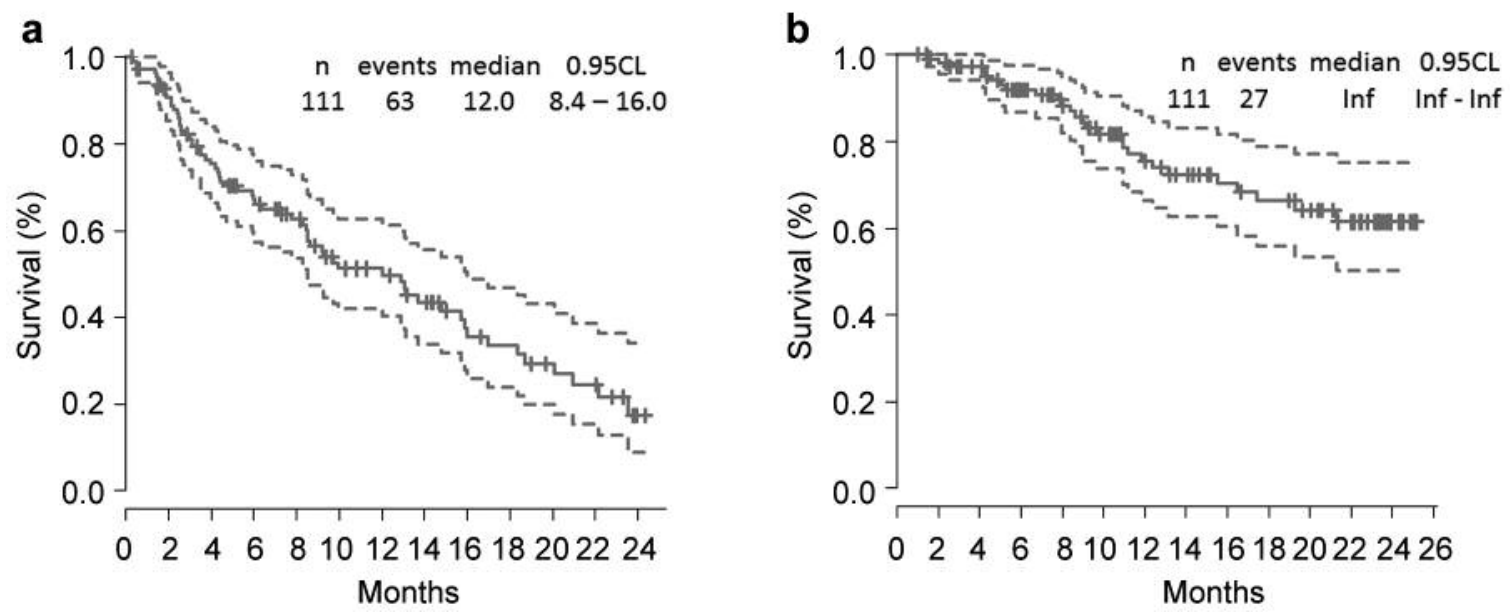

Figure 1. Kaplan-Meier plots for (a) progression-free survival and (b) overall survival of osimertinib in eligible patients.
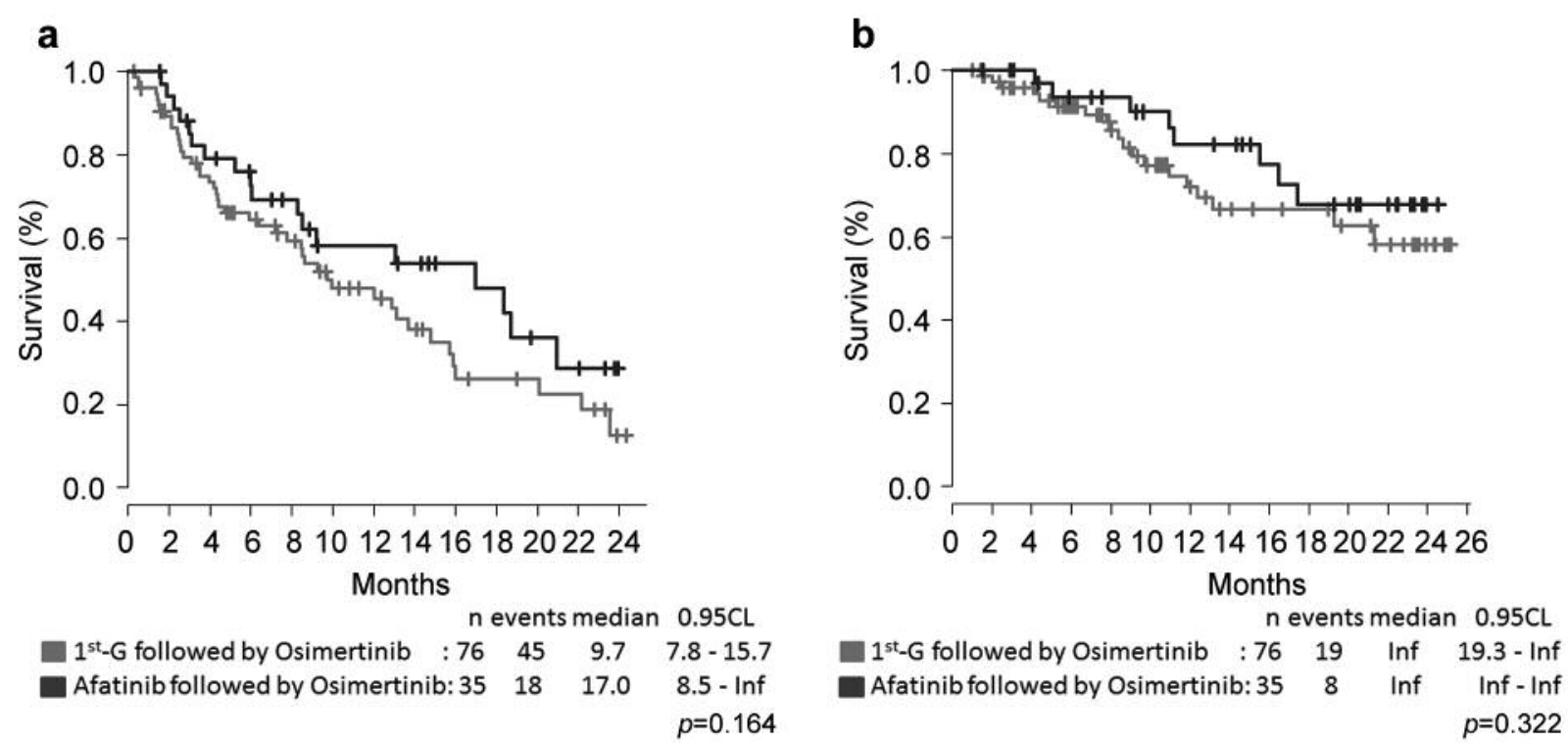

Figure 2. Kaplan-Meier plots for (a) progression-free survival and (b) overall survival of osimertinib following between afatinib and 1 st generation EGFR-TKIs (gefitinib or erlotinib).

analysis showed similar results to the analyses we conducted in this study. Our results showed that treatment with osimertinib following afatinib showed significantly better responses than osimertinib following 1st-G EGFR-TKI.

These differences of effects may result from an induction of tumor heterogeneity during afatinib or 1st-G EGFR-TKI treatment. It is generally accepted that tumors undergo complex evolution over the course of their development and during cancer treatment, thus resulting in a further increase in tumor heterogeneity $(24,25)$. Recent studies have implemented the construction of divergence-based phylogenetic trees to illustrate tumor development including in cases of NSCLC $(26,27)$. Truncal mutations are clonal mutations that are present in all tumor cells and regions, and branch mutation are later subclonal events that are present in only a small proportion of tumor cells, resulting in intratumoral clonal diversity $(27,28)$. A recent study showed a high prevalence of other common genetic mutations 
besides EGFR mutations in advanced-stage EGFR mutationpositive NSCLC (29). These additional aberrations included known oncogenic drivers in intracellular signaling and cell cycle pathway genes (25). Furthermore, this analysis also indicated that co-occurring mutations are very common in T790M-positive tumors. Therefore, the heterogeneity of EGFR mutations in EGFR mutation-positive NSCLC has potential clinical implications since different EGFR TKIs have varying effectiveness dependent on the specific mutation. Preclinical studies indicate that 2nd-G EGFR-TKIs may have a broader inhibitory profile against various types of EGFR mutations compared to 1st- or 3rd-G EGFR-TKIs (30-32). Furthermore, afatinib showed more potency than gefitinib, erlotinib, and osimertinib against compound mutations (32). Conversely, the clinical benefits of osimertinib are superior if co-occurring genetic alternations are present in advanced T790M-positive NSCLC (29). Our results may be explained by the possibility that afatinib may exhibit increased efficacy by targeting co-occurring genetic diversity in EGFR mutations leading to enrichment of T790M cells than 1 st-G EGFR-TKIs.

There are certain limitations to our study. Due to its retrospective nature, information bias cannot be excluded. Additionally, there are some differences in patient characteristics between two groups that may have skewed the results. Some factors in the afatinib group were inferior, compared to 1st-G EGFR-TKI group; however, the overall outcome was better in the afatinib group. This result may further strengthen our hypothesis. Second, the follow-up time was not sufficient to calculate the full long-term survival outcome measure. Finally, we could not analyze the overall survival from the first-line chemotherapy because of difference in the number of prior chemotherapies prior to osimertinib treatment. We classified the afatinib group or 1 st-G group by last administration of EGFR-TKI before osimertinib therapy initiation. Therefore, there were some patients treated with afatinib and 1st-G EGFR-TKI in both groups. However, a study by Imamura et al. showed plasma mutation scores of EGFR circulating tumor DNA with activating mutations decreased rapidly in response to EGFRTKI within at least 14 days (33). Therefore, we think that the effect of osimertinib is potentiated mainly by the last EGFRTKI prior to osimertinib initiation even if this exposure is for a very short duration, and we found that results of our study is in-line with that of a recent observational study (20).

\section{Conclusion}

Afatinib followed by osimertinib may provide better benefit for NSCLC harboring T790M-positive mutations than the use of other first-generation EGFR-TKIs. We believe that afatinib followed by osimertinib is one of the best therapeutic options for NSCLC harboring EGFR mutations.

\section{Funding}

This research did not receive any specific grant from funding agencies in the public, commercial, or not-for-profit sectors.

\section{Ethical Approval}

All procedures performed in studies involving human participants were in accordance with the ethical standards of the institutional and with the 1964 Helsinki declaration and its later amendments or comparable ethical standards.

\section{Informed Consent}

Informed consent was obtained from all individual participants included in the study.

\section{Conflicts of Interest}

All Authors report no conflicts of interest.

\section{Authors' Contributions}

M. Tamiya and A. Tamiya designed the study, and wrote the initial draft of the manuscript. M. Tamiya, A. Tamiya, and H. Suzuki contributed to analysis and interpretation of data, and assisted in the preparation of the manuscript. All other Authors have contributed to data collection and interpretation, and critically reviewed the manuscript. All Authors approved the final version of the manuscript, and agree to be accountable for all aspects of the work in ensuring that questions related to the accuracy or integrity of any part of the work are appropriately investigated and resolved.

\section{Acknowledgements}

The Authors wish to thank all the patients who participated in this study.

\section{References}

1 Hoffman PC, Mauer AM and Vokes EE: Lung cancer. Lancet 355: 479-485, 2000. PMID: 10841143. DOI: 10.1016/S01406736(00)82038-3

2 Schiller JH, Harrington D, Belani CP, Langer C, Sandler A, Krook J, Zhu J and Johnson DH: Comparison of four chemotherapy regimens for advanced non-small-cell lung cancer. N Engl J Med 346: 92-98, 2002. DOI: 10.1056/NEJMoa011954

3 Herbst RS, Heymach JV and Lippman SM: Lung cancer. N Engl J Med 359: 1367-1380, 2008. PMID: 18815398. DOI: 10.1056/ NEJMra0802714

4 Maemondo M, Inoue A, Kobayashi K, Sugawara S, Oizumi S, Isobe H, Gemma A, Harada M, Yoshizawa H, Kinoshita I, Fujita Y Okinaga S, Hirano H, Yoshimori K, Harada T, Ogura T, Ando M, Miyazawa H, Tanaka T, Saijo Y, Hagiwara K, Morita S and Nukiwa T: Gefitinib or chemotherapy for non-small-cell lung cancer with mutated EGFR. N Engl J Med 362: 2380-2388, 2010. PMID: 20573926. DOI: 10.1056/NEJMoa0909530 
5 Mitsudomi T, Morita S, Yatabe Y, Negoro S, Okamoto I, Tsurutani J, Seto T, Satouchi M, Tada H, Hirashima T, Asami K, Katakami N, Takada M, Yoshioka H, Shibata K, Kudoh S, Shimizu E, Saito H, Toyooka S, Nakagawa K and Fukuoka M: Gefitinib versus cisplatin plus docetaxel in patients with nonsmall-cell lung cancer harbouring mutations of the epidermal growth factor receptor (WJTOG3405): an open label, randomised phase 3 trial. Lancet Oncol 11: 121-128, 2010. PMID: 20022809. DOI: 10.1016/S1470-2045(09)70364-X

6 Zhou C, Wu YL, Chen G, Feng J, Liu XQ, Wang C, Zhang S, Wang J, Zhou S, Ren S, Lu S, Zhang L, Hu C, Hu C, Luo Y, Chen L, Ye M, Huang J, Zhi X, Zhang Y, Xiu Q, Ma J, Zhang L and You C: Erlotinib versus chemotherapy as first-line treatment for patients with advanced EGFR mutation-positive non-smallcell lung cancer (OPTIMAL, CTONG-0802): A multicentre, open-label, randomised, phase 3 study. Lancet Oncol 12: 735742, 2011. PMID: 21783417. DOI: 10.1016/S1470-2045(11) 70184-X

7 Rosell R, Carcereny E, Gervais R, Vergnenegre A, Massuti B, Felip E, Palmero R, Garcia-Gomez R, Pallares C, Sanchez JM, Porta R, Cobo M, Garrido P, Longo F, Moran T, Insa A, De Marinis F, Corre R, Bover I, Illiano A, Dansin E, de Castro J, Milella M, Reguart N, Altavilla G, Jimenez U, Provencio M, Moreno MA, Terrasa J, Muñoz-Langa J, Valdivia J, Isla D, Domine M, Molinier O, Mazieres J, Baize N, Garcia-Campelo R, Robinet G, Rodriguez-Abreu D, Lopez-Vivanco G, Gebbia V, Ferrera-Delgado L, Bombaron P, Bernabe R, Bearz A, Artal A, Cortesi E, Rolfo C, Sanchez-Ronco M, Drozdowskyj A, Queralt C, de Aguirre I, Ramirez JL, Sanchez JJ, Molina MA, Taron M and Paz-Ares L: Erlotinib versus standard chemotherapy as firstline treatment for European patients with advanced EGFR mutation-positive non-small-cell lung cancer (EURTAC): a multicentre, open-label, randomised phase 3 trial. Lancet Oncol 13: 239-246, 2012. PMID: 22285168. DOI: 10.1016/S14702045(11)70393-X

8 Yang JC, Sequist LV, Geater SL, Tsai CM, Mok TS, Schuler M, Yamamoto N, Yu CJ, Ou SH, Zhou C, Massey D, Zazulina V and $\mathrm{Wu}$ YL: Clinical activity of afatinib in patients with advanced non-small-cell lung cancer harbouring uncommon EGFR mutations: a combined post-hoc analysis of LUX-Lung 2, LUX-Lung 3, and LUX-Lung 6. Lancet Oncol 16: 830-838, 2015. PMID: 26051236. DOI: 10.1016/S1470-2045(15)00026-1

9 Park K, Tan EH, O’Byrne K, Zhang L, Boyer M, Mok T, Hirsh V, Yang JC, Lee KH, Lu S, Shi Y, Kim SW, Laskin J, Kim DW, Arvis CD, Kölbeck K, Laurie SA, Tsai CM, Shahidi M, Kim M, Massey D, Zazulina V and Paz-Ares L: Afatinib versus gefitinib as first-line treatment of patients with EGFR mutation-positive non-small-cell lung cancer (LUX-Lung 7): A phase 2B, openlabel, randomised controlled trial. Lancet Oncol 17: 577-589, 2016. PMID: 27083334. DOI: 10.1016/S1470-2045(16)30033-X

10 Arcila ME, Oxnard GR, Nafa K, Riely GJ, Solomon SB, Zakowski MF, Kris MG, Pao W, Miller VA and Ladanyi M: Rebiopsy of lung cancer patients with acquired resistance to EGFR inhibitors and enhanced detection of the T790M mutation using a locked nucleic acid-based assay. Clin Cancer Res 17: 1169-1180, 2011. PMID: 21248300. DOI: 10.1158/1078-0432. CCR-10-2277

11 Nosaki K, Satouchi M, Kurata T, Yoshida T, Okamoto I, Katakami N, Imamura F, Tanaka K, Yamane Y, Yamamoto N, Kato T, Kiura K, Saka H, Yoshioka H, Watanabe K, Mizuno K and Seto T: Re-biopsy status among non-small cell lung cancer patients in Japan: A retrospective study. Lung Cancer 101: 1-8, 2016. PMID: 27794396. DOI: 10.1016/j.lungcan.2016.07.007

12 Kuiper JL, Heideman DA, Thunnissen E, Paul MA, van Wijk AW, Postmus PE and Smit EF: Incidence of T790M mutation in (sequential) rebiopsies in EGFR-mutated NSCLC-patients. Lung Cancer 85: 19-24, 2014. PMID: 24768581. DOI: 10.1016/ j.lungcan.2014.03.016

13 Kogure K, Shigematsu F, Oki M and Saka H: T790M correlates with longer progression-free survival in non-small cell lung carcinomas harboring EGFR mutations. In Vivo 32: 1199-1204, 2018. PMID: 30150444. DOI: 10.21873/invivo.11364

14 Cross DA, Ashton SE, Ghiorghiu S, Eberlein C, Nebhan CA, Spitzler PJ, Orme JP, Finlay MR, Ward RA, Mellor MJ, Hughes G, Rahi A, Jacobs VN, Red Brewer M, Ichihara E, Sun J, Jin H, Ballard P, Al-Kadhimi K, Rowlinson R, Klinowska T, Richmond GH, Cantarini M, Kim DW, Ranson MR and Pao W: AZD9291, an irreversible EGFR TKI, overcomes T790M-mediated resistance to EGFR inhibitors in lung cancer. Cancer Discov 4: 1046-1061, 2014. PMID: 24893891. DOI: 10.1158/2159-8290.CD-14-0337

15 Jänne PA, Yang JC, Kim DW, Planchard D, Ohe Y, Ramalingam SS, Ahn MJ, Kim SW, Su WC, Horn L, Haggstrom D, Felip E, Kim JH, Frewer P, Cantarini M, Brown KH, Dickinson PA, Ghiorghiu S and Ranson M: AZD9291 in EGFR inhibitorresistant non-small-cell lung cancer. N Engl J Med 372: 16891699, 2015. PMID: 2592359. DOI: 10.1056/NEJMoa1411817

16 Mok TS, Wu Y-L, Ahn M-J, Garassino MC, Kim HR, Ramalingam SS, Shepherd FA, He Y, Akamatsu H, Theelen WS, Lee CK, Sebastian M, Templeton A, Mann H, Marotti M, Ghiorghiu S and Papadimitrakopoulou VA: Osimertinib or platinum-pemetrexed in EGFR T790M-positive lung cancer. N Engl J Med 376: 629-640, 2017. PMID: 27959700. DOI: 10.1056/NEJMoa1612674

17 Soria JC, Ohe Y, Vansteenkiste J, Reungwetwattana T, Chewaskulyong B, Lee KH, Dechaphunkul A, Imamura F, Nogami N, Kurata T, Okamoto I, Zhou C, Cho BC, Cheng Y, Cho EK, Voon PJ, Planchard D, Su WC, Gray JE, Lee SM, Hodge R, Marotti M, Rukazenkov Y and Ramalingam SS: Osimertinib in untreated EGFR-mutated advanced non-small-cell lung cancer. N Engl J Med 378: 113-125, 2018. PMID: 29151359. DOI: 10.1056/NEJMoa1713137

18 Oxnard GR, Hu Y, Mileham KF, Husain H, Costa DB, Tracy P, Feeney N, Sholl LM, Dahlberg SE, Redig AJ, Kwiatkowski DJ, Rabin MS, Paweletz CP, Thress KS and Jänne PA: Assessment of resistance mechanisms and clinical implications in patients with EGFR T790M-positive lung cancer and acquired resistance to osimertinib. JAMA Oncol 4: 1527-1534, 2018. PMID: 30073261. DOI: 10.1001/jamaoncol.2018.2969

19 Niederst MJ, Hu H, Mulvey HE, Lockerman EL, Garcia AR, Piotrowska Z, Sequist LV and Engelman JA: The allelic context of the C797S mutation acquired upon treatment with thirdgeneration EGFR inhibitors impacts sensitivity to subsequent treatment strategies. Clin Cancer Res 21: 3924-3933, 2015. PMID: 25964297. DOI: 10.1158/1078-0432.CCR-15-0560

20 Hochmair MJ, Morabito A, Hao D, Yang CT, Soo RA, Yang JC, Gucalp R, Halmos B, Wang L, Golembesky A, Märten A and Cufer T: Sequential treatment with afatinib and osimertinib in patients with EGFR mutation-positive non-small-cell lung cancer: an observational study. Future Oncol 14: 2861-2874, 2018. PMID: 30336693. DOI: 10.2217/fon-2018-0711 
21 Park K, Bennouna J, Boyer M, Hida T, Hirsh V, Kato T, Lu S Mok T, Nakagawa K, O'Byrne K, Puz-Ares L, Schuler M, Sibilot DM, Tan EH, Tanako H, Wu YL, Yang JCH, Zhang L, Zhou C, Marten A, Tang W and Yamamoto N: Sequencing of therapy following first-line afatinib in patients with EGFR mutation-positive non small cell lung cancer. Lung Cancer 9, 2019. DOI: 10.1016/j.lungcan.2019.04.014

22 Eisenhauer EA, Therasse P, Bogaerts J, Schwartz LH, Sargent D, Ford R, Dancey J, Arbuck S, Gwyther S, Mooney M, Rubinstein L, Shankar L, Dodd L, Kaplan R, Lacombe D and Verweij J: New response evaluation criteria in solid tumours: Revised RECIST guideline (version 1.1). Eur J Cancer 45: 228247, 2009. PMID: 19097774. DOI: 10.1016/j.ejca.2008.10.026

23 Paz-Ares L, Tan EH, O’Byrne K, Zhang L, Hirsh V, Boyer M, Yang JC, Mok T, Lee KH, Lu S, Shi Y, Lee DH, Laskin J, Kim DW, Laurie SA, Kölbeck K, Fan J, Dodd N, Märten A and Park $\mathrm{K}$ : Afatinib versus gefitinib in patients with EGFR mutationpositive advanced non-small-cell lung cancer: overall survival data from the phase IIb LUX-Lung 7 trial. Ann Oncol 28: 270277, 2017. PMID: 28426106. DOI: 10.1093/annonc/mdw611

24 Nowell PC: The clonal evolution of tumor cell populations. Science 194: 23-28, 1976. PMID: 959840.

25 Nahar R, Zhai W, Zhang T, Takano A, Khng AJ, Lee YY, Liu X, Lim CH, Koh TPT, Aung ZW, Lim TKH, Veeravalli L, Yuan J, Teo ASM, Chan CX, Poh HM, Chua IML, Liew AA, Lau DPX, Kwang XL, Toh CK, Lim WT, Lim B, Tam WL, Tan EH, Hillmer AM and Tan DSW: Elucidating the genomic architecture of Asian EGFR-mutant lung adenocarcinoma through multiregion exome sequencing. Nat Commun 9: 216, 2018. PMID: 5768770. DOI: 10.1038/s41467-017-02584-Z

26 Gerlinger M, Rowan AJ, Horswell S, Math M, Larkin J, Endesfelder D, Gronroos E, Martinez P, Matthews N, Stewart A, Tarpey P, Varela I, Phillimore B, Begum S, McDonald NQ, Butler A, Jones D, Raine K, Latimer C, Santos CR, Nohadani M, Eklund AC, Spencer-Dene B, Clark G, Pickering L, Stamp G, Gore M, Szallasi Z, Downward J, Futreal PA and Swanton C: Intratumor heterogeneity and branched evolution revealed by multiregion sequencing. N Engl J Med 366: 883-892, 2012. PMID: 22397650. DOI: 10.1056/NEJMoa1113205

27 de Bruin EC, McGranahan N, Mitter R, Salm M, Wedge DC, Yates L, Jamal-Hanjani M, Shafi S, Murugaesu N, Rowan AJ, Grönroos E, Muhammad MA, Horswell S, Gerlinger M, Varela I, Jones D, Marshall J, Voet T, Van Loo P, Rassl DM, Rintoul RC, Janes SM, Lee SM, Forster M, Ahmad T, Lawrence D, Falzon M, Capitanio A, Harkins TT, Lee CC, Tom W, Teefe E, Chen SC, Begum S, Rabinowitz A, Phillimore B, Spencer-Dene B, Stamp G, Szallasi Z, Matthews N, Stewart A, Campbell P and Swanton C: Spatial and temporal diversity in genomic instability processes defines lung cancer evolution. Science 346: 251-256, 2014. PMID: 25301630. DOI: 10.1126/science.1253462
28 Burrell RA and Swanton C: Re-evaluating clonal dominance in cancer evolution. Trends Cancer 2: 263-276, 2016. PMID: 28741512. DOI: 10.1016/j.trecan.2016.04.002

29 Blakely CM, Watkins TBK, Wu W, Gini B, Chabon JJ, McCoach CE, McGranahan N, Wilson GA, Birkbak NJ, Olivas VR, Rotow J, Maynard A, Wang V, Gubens MA, Banks KC, Lanman RB, Caulin AF, St John J, Cordero AR, Giannikopoulos P, Simmons AD, Mack PC, Gandara DR, Husain H, Doebele RC, Riess JW, Diehn M, Swanton C and Bivona TG: Evolution and clinical impact of co-occurring genetic alterations in advanced-stage EGFR-mutant lung cancers. Nat Genet 49: 1693-1704, 2017. PMID: 29106415. DOI: 10.1038/ng.3990

30 Kobayashi Y and Mitsudomi T: Not all epidermal growth factor receptor mutations in lung cancer are created equal: Perspectives for individualized treatment strategy. Cancer Sci 107: 11791186, 2016. PMID: 27323238. DOI: 10.1111/cas.12996

31 Kobayashi Y, Togashi Y, Yatabe Y, Mizuuchi H, Jangchul P, Kondo C, Shimoji M, Sato K, Suda K, Tomizawa K, Takemoto T, Hida T, Nishio K and Mitsudomi T: EGFR Exon 18 mutations in lung cancer: Molecular predictors of augmented sensitivity to afatinib or neratinib as compared with first- or third-generation TKIs. Clin Cancer Res 21: 5305-5313, 2015. PMID: 26206867. DOI: 10.1158/1078-0432.CCR-15-1046

32 Kohsaka S, Nagano M, Ueno T, Suehara Y, Hayashi T, Shimada N, Takahashi K, Suzuki K, Takamochi K, Takahashi F and Mano $\mathrm{H}$ : A method of high-throughput functional evaluation of EGFR gene variants of unknown significance in cancer. Sci Transl Med 9, 2017. PMID: 29141884. DOI: 10.1126/scitranslmed.aan6566

33 Imamura F, Uchida J, Kukita Y, Kumagai T, Nishino K, Inoue T, Kimura M and Kato K: Early responses of EGFR circulating tumor DNA to EGFR tyrosine kinase inhibitors in lung cancer treatment. Oncotarget 7: 71782-71789, 2016. PMID: 27708242. DOI: $10.18632 /$ oncotarget.12373
Received April 8, 2019

Revised April 28, 2019

Accepted April 30, 2019 